FLOOD OF NOVEMBER 26-27, 1979, IN ESSEX COUNTY, NEW YORK

by Thomas J. Zembrzuski, Jr.

U.S. GEOLOGICAL SURVEY

Open-File Report $80-1024$

Prepared in cooperation with the

NEW YORK STATE DEPARTMENT OF TRANSPORTATION

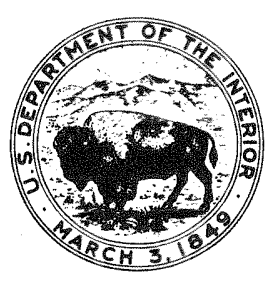

Albany, New York

1981 


\author{
UNITED STATES DEPARTMENT OF THE INTERIOR \\ JAMES G. WATT, Secretary \\ GEOLOGICAL SURVEY \\ Doyle G. Frederick, Acting Director
}

For additional information write to:

U.S. Geological Survey

P.0. Box 1350

Albany, New York 12201

(518) 472-3107 
Conversion factors and abbreviations..................... iv

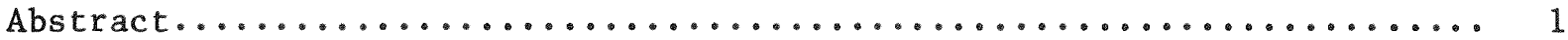

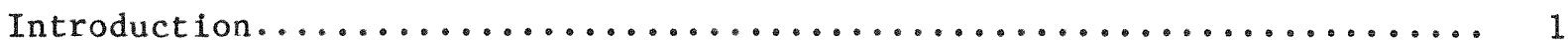

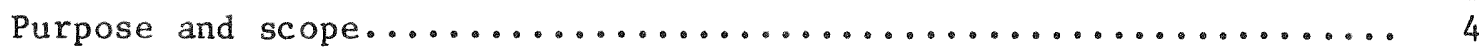

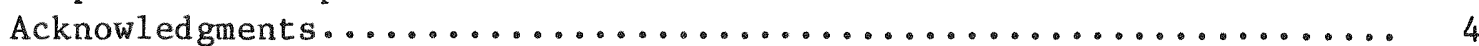

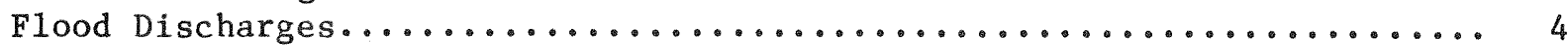

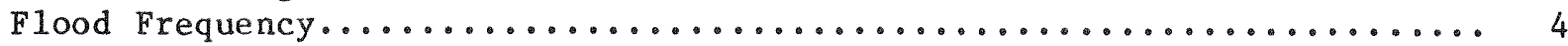

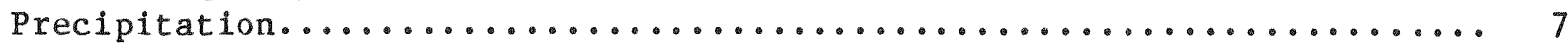

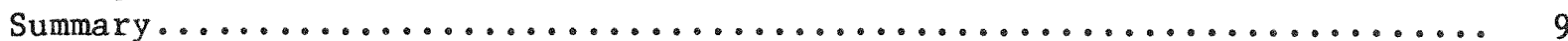

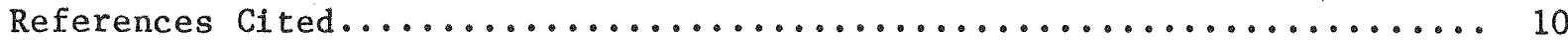

\section{TABLES}

Table 1. Summary of flood discharges in northeastern New York during

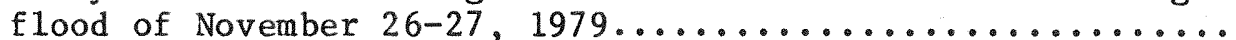

2. Recurrence interval of discharges of selected streams during flood of November 26-27, 1979, Elizabethtown, N.Y....

3. Rainfal1-frequency relationships for storms of 3- and

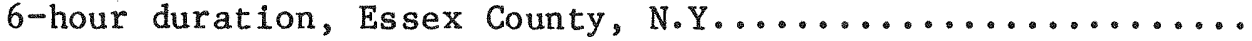

\section{ILLUSTRATIONS}

Figure 1. Map showing major geographic features of Bouquet River and the East Branch Ausable River basins,

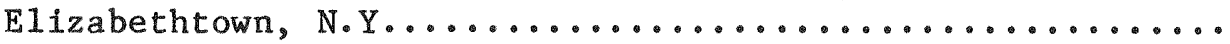

2. Photographs showing washout of New York State Highway $9 \mathrm{~N}$ along The Branch near Elizabethtown, N.Y.,

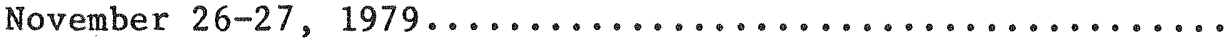

3. Map showing locations of gaging stations and precipitation

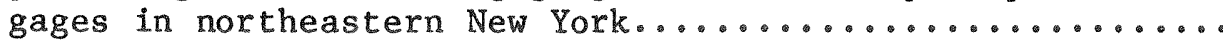

4. Flood-frequency curve for station 04276215 The Branch near

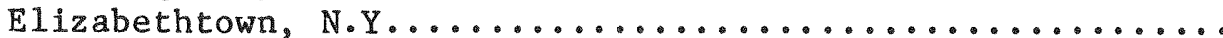




\section{CONVERSION FACTORS AND ABBREVIATIONS}

The following factors may be used to convert units of measurement used in this report to the International System (SI) of metric units.

\begin{tabular}{lcl} 
Multiply Inch-Pound Units & By & To obtain SI units \\
\hline inch (in) & 25.4 & millimeter (mm) \\
foot (ft) & 0.3048 & meter (m) $(\mathrm{km})$ \\
mile (mi) & 1.609 & kilometer \\
square mile (mi2) & 2.590 & kilometer (km $\left.{ }^{2}\right)$ \\
cubic foot per second & 0.02832 & cubic meter per second \\
$\quad(\mathrm{ft} 3 / \mathrm{s})$ & & $\left(\mathrm{m}^{3} / \mathrm{s}\right)$
\end{tabular}




\title{
FLOOD OF NOVEMBER 26-27, 1979 IN ESSEX COUNTY, NEW YORK
}

By

Thomas J. Zembrzuski, Jr.

\begin{abstract}
On November 26-27, 1979, flash flooding of several streams in Essex County resulted in five deaths and millions of dollars' worth in property damage. The most severe flooding was in the headwaters of the Bouquet and East Branch Ausable miver basins. Peak discharge of The Branch, the Bouquet River tributary on which a section of highway washed out, was 6,600 cubic feet per second at a measurement site 1 mile west of Elizabethtown. The recurrence interval of this discharge is estimated to be greater than 100 years (exceedance probability less than 0.01 ).
\end{abstract}

\section{INTRODUCTION}

On the evening of November 26, 1979, flash flooding of several streams in Essex County resulted in five deaths and millions of dollars' worth in damage to highways, bridges, and private property (Brady, 1979). The fatalities occurred on The Branch, a tributary to the Bouquet River, at a washout of New York State Highway $9 \mathrm{~N}$ about 2 miles west of Elizabethtown (fig. 1). The storm was localized; runoff patterns indicate that its heaviest intensity was at the headwaters of the Bouquet and East Branch Ausable Rivers. At the gaging station on East Branch Ausable River at Au Sable Forks (station 04275000), the flood was the largest since the New Year's Flood of 1949, and, at the creststage gage on the Bouquet River at New Russia (04276200), it was the largest in the gage's 31-year period of operation.

The severity was not evident from the precipitation gage data. A total of 2.73 inches (0.96 inches on November 25 and 1.77 inches on November 26) was measured at the National Weather Service (NWS) nonrecording precipitation gage in Elizabethtown, but a survey made by NWS after the storm indicates that rainfall totals could have exceeded 5 inches in the mountains south and west of Elizabethtown.

Figure 1 shows location of major streams and highways in the area; figure 2 shows the collapsed part of Highway $9 \mathrm{~N}$. 


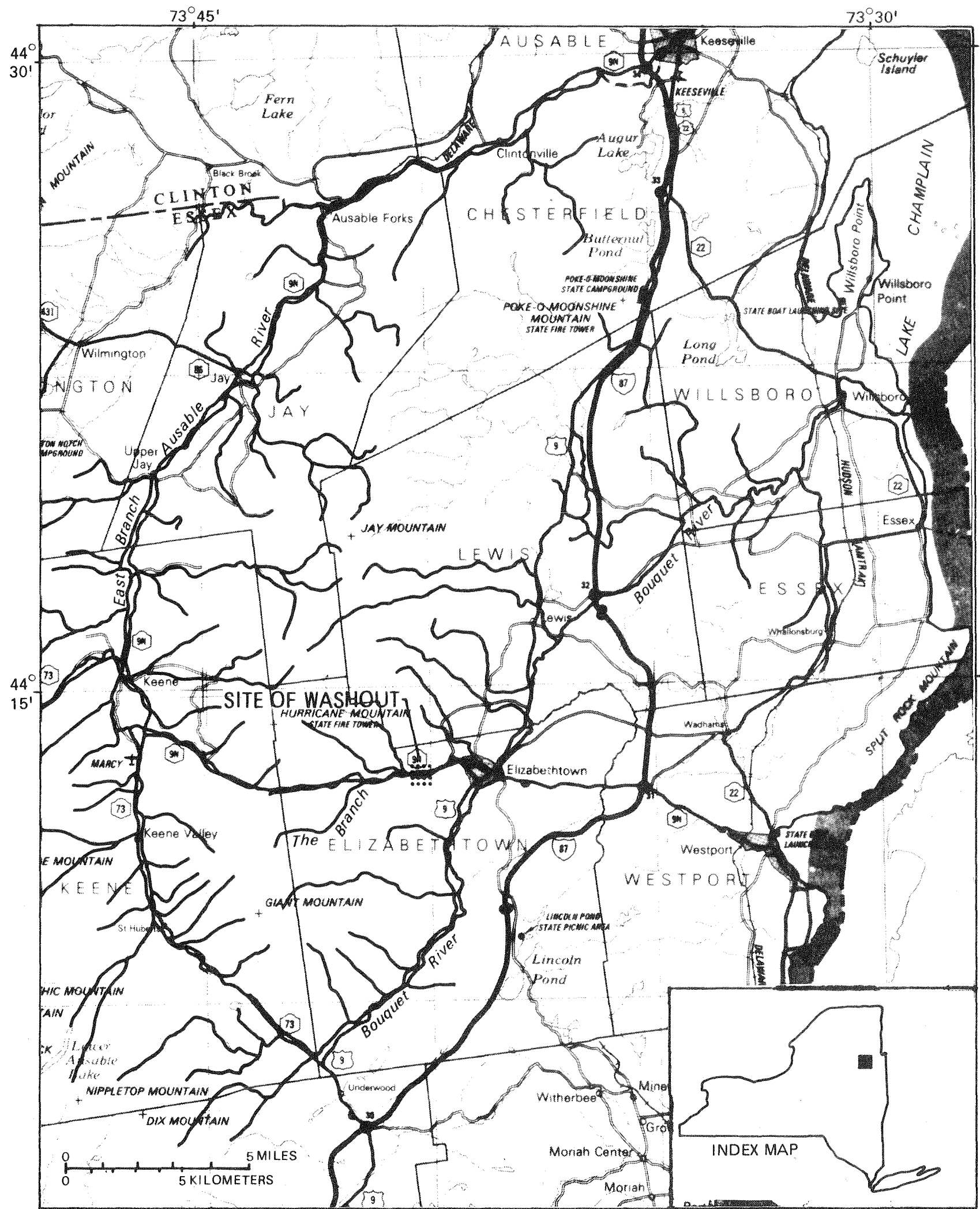

Base from N.Y.S. Department of Transportation, 1980 NORTH SHEET, 1:250,000

Figure 1.--Major geographic features of Bouquet River and The Branch basins, Elizabethtown, N.Y. 

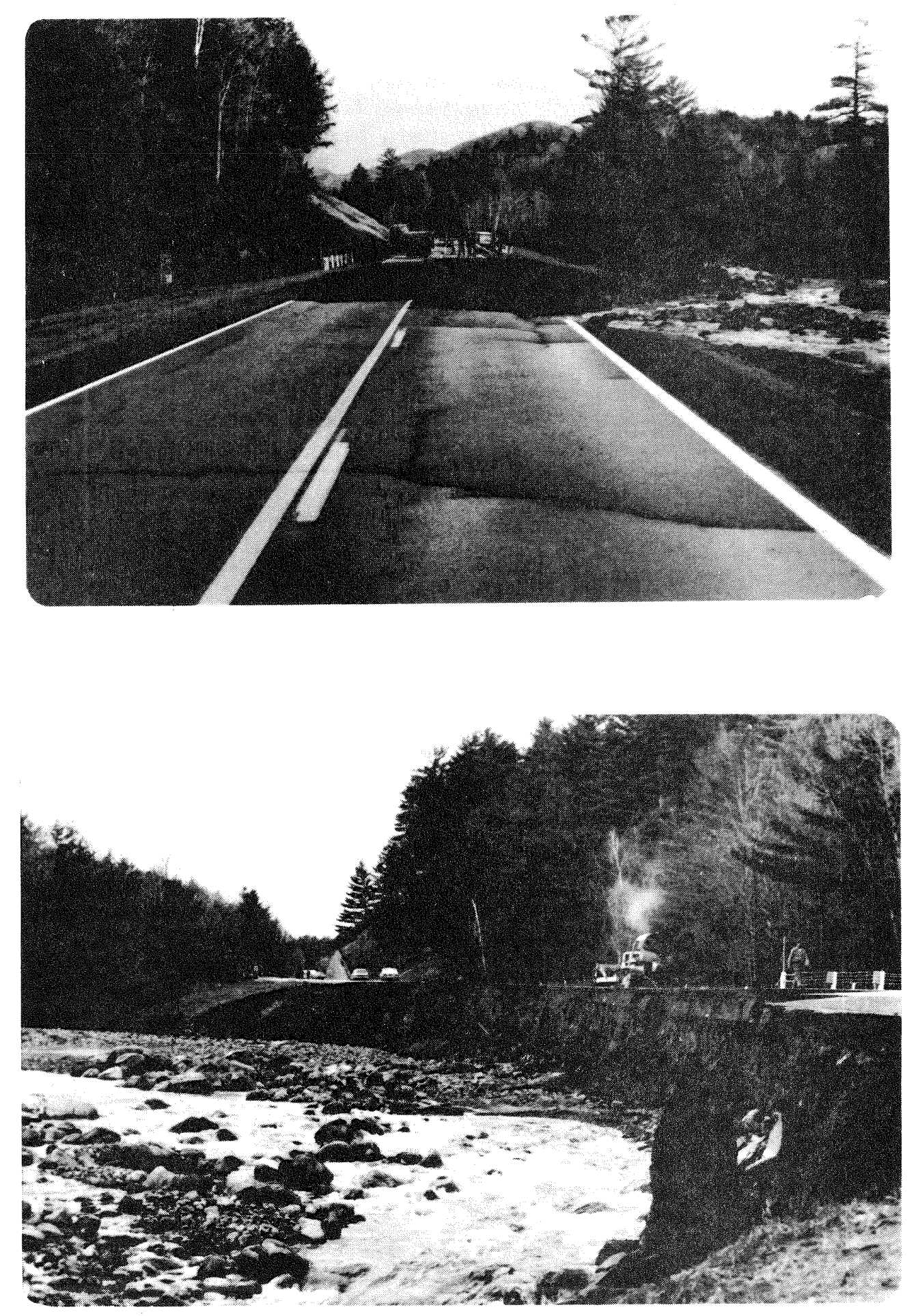

Eigure 2.-Washout of New York State Highway $9 \mathrm{~N}$ along The Branch near EZizabethtown, N.Y., November 26-27, 1979. Top, view from highway, looking east; bottom, view from miver bank, looking west. 


\section{Purpose and Scope}

As part of a continuing program with the New York State Department of Transportation to document major floods in New York State, the U.S. Geological Survey compiled hydrologic data on this flood from both active and discontinued stream-gaging stations in northeastern New York and made an indirect discharge measurement to determine peak flow of The Branch 0.7 mile downstream from the site of the washout on Highway $9 \mathrm{~N}$. This report presents data on the 1979 flood in comparison to record floods within the region and gives the recurrence interval of the peak discharges of selected streams.

\section{Acknowlegments}

Rainfall data for the November $26-27$ storm were provided by the National Weather Service in Albany, N.Y., and the Atmospheric Sciences Research Center, Albany, N.Y.

\section{FLOOD DISCHARGES}

Although the most severe floods were in the Bouquet and East Branch Ausable River basins (fig. 1), high water occurred throughout much of northeastern New York. Peak-discharge data collected at gaging stations are presented in table 1; location of the gaging stations is shown in figure 3.

In addition to the compilations mentioned above, an indirect discharge measurement was made by the slope-area method (Dalrymple and Benson, 1967) on The Branch $1.0 \mathrm{mi}$ west of Elizabethtown and $0.7 \mathrm{mi}$ downstream from the washout on Highway $9 \mathrm{~N}$. The slope-area reach had four sections and a computed discharge of $6,600 \mathrm{ft} 3 / \mathrm{s}$. Average cross-sectional flow velocities in the slope-area reach ranged from $12.2 \mathrm{ft} / \mathrm{s}$ to $14.2 \mathrm{ft} / \mathrm{s}$.

\section{FLOOD FREQUENCY}

The discharge-frequency relationship of a streamflow-measurement site is generally expressed in terms of recurrence interval or exceedance probability. (Recurrence interval is, conceptually, the average time interval between actual occurrences of a flood of equal or greater magnitude. Exceedance probability, the reciprocal of recurrence interval, is the probability that a flood of specified magnitude will be equaled or exceeded in any one year.) 
Table 1.--Summary of flood discharges in northeastern New York during flood of November 26-27, 1979

[Station locations are shown in fi.g. 3]

\begin{tabular}{|c|c|c|c|c|c|c|c|c|c|c|c|c|}
\hline \multirow{4}{*}{$\begin{array}{l}\text { Station } \\
\text { number }\end{array}$} & \multirow[b]{4}{*}{ Stream and measurement site } & \multirow{4}{*}{$\begin{array}{l}\text { Drainage } \\
\quad \text { area } \\
(\mathrm{mi} 2)\end{array}$} & \multirow{4}{*}{$\begin{array}{l}\text { Period } \\
\text { of } \\
\text { record }\end{array}$} & Maximum & \multicolumn{2}{|c|}{ flood previously } & known & \multicolumn{5}{|c|}{ Maximum during November 1979} \\
\hline & & & & \multirow[b]{3}{*}{ Date } & \multirow{3}{*}{$\begin{array}{l}\text { Gage } \\
\text { helght } \\
\text { (ft) }\end{array}$} & \multirow{2}{*}{\multicolumn{2}{|c|}{ Discharge }} & \multirow{2}{*}{\multicolumn{3}{|c|}{$\begin{array}{c}\text { Gage } \\
\text { height }\end{array}$}} & \multirow{2}{*}{\multicolumn{2}{|c|}{ Discharge }} \\
\hline & & & & & & & & & & & & \\
\hline & & & & & & $\mathrm{ft}^{3 / \mathrm{s}}($ & $\left(\mathrm{ft}^{3 / \mathrm{s}}\right) / \mathrm{mi} 2$ & Date & Time & $(\mathrm{ft})$ & $\mathrm{ft}^{3 / \mathrm{s}}($ & $\left(\mathrm{ft}^{3 / \mathrm{s}) / \mathrm{mi} 2}\right.$ \\
\hline 01312000 & Hudson River at Newcomb & 192 & 1925- & $01-01-49$ & 11.40 & 7,440 & 38.8 & 26 & 2400 & 7.14 & 3,370 & 17.6 \\
\hline 01315000 & Indian River near Indian Lake & 132 & $\begin{array}{l}1912-14 \\
1915-\end{array}$ & $03-28-13$ & 7.8 & 3,460 & 26.2 & 26 & 2000 & 2.76 & 486 & 3.7 \\
\hline 01315500 & Hudson River at North Creek & 792 & $1907-$ & $12-31-48$ & 12.14 & 28,900 & 36.5 & 27 & 1230 & 8.98 & 13,300 & 16.8 \\
\hline 01318500 & Hudson River at Hadley & 1664 & $1921-$ & $01-01-49$ & 21,21 & 42,700 & 25.7 & 27 & 2100 & 10.44 & 16,400 & 9.9 \\
\hline 01319800 & West Branch Sacandaga River at Arietta & 28.9 & $1963-$ & $03-05-64$ & 12.73 & 1,860 & 64.4 & 27 & - & 11.02 & 1,050 & 36.3 \\
\hline 01321000 & Sacandaga River near Hope & 491 & $1911-$ & $03-27-13$ & 11.0 & 32,000 & 65.2 & 27 & 0230 & 7.93 & 14,900 & 30.3 \\
\hline 01327750 & Hudson River at Ft. Edward & 2817 & $1976-$ & $04-29-79$ & 28.09 & 34,000 & 12.1 & 28 & 0300 & 25.12 & 20,900 & 7.4 \\
\hline \multirow[t]{2}{*}{01328000} & Bond Creek at Dunham Basin & 14.7 & $1943-$ & $12-31-48$ & 8.52 & 1,370 & 93.2 & 27 & 0115 & 3.63 & 207 & 14.1 \\
\hline & ST. LAWRENCE RIVER BASIN & & & & & & & & & & & \\
\hline 04261000 & Oswegatchie River at Cranberry Lake & 144 & 1923- & $05-13-43$ & 7.70 & 1,940 & 13.5 & 30 & 1800 & 5.79 & 630 & 4.4 \\
\hline 04266500 & Raquette River at Plercefield & 722 & $1908-$ & $05-08-72$ & 12.25 & 8,360 & 11.6 & 30 & 0330 & 8.12 & 3,000 & 4.2 \\
\hline \multirow[t]{2}{*}{04270000} & Salmon River at Chasm Falls & 132 & $1925-$ & $04-25-26$ & 5.0 & 2,890 & 21.9 & 27 & 0745 & 2.99 & 939 & 7.1 \\
\hline & STREAMS DRAINING INTO LAKE CHAMPLAIN & & & & & & & & & & & \\
\hline 04273500 & Saranac River at Plattsburg & 608 & $\begin{array}{l}1903-30 \\
1943-\end{array}$ & $04-08-28$ & - & 11,500 & 18.9 & 27 & 1600 & 5.46 & 2,210 & 3.6 \\
\hline 04273700 & Saranac River at South Plattsburg & 61.9 & $\begin{array}{l}1960-68 \\
69,71-\end{array}$ & $03-05-74$ & 5.60 & 1,600 & 25.8 & 27 & 0600 & 2.55 & 230 & 3.7 \\
\hline 04274000 & $\begin{array}{l}\text { West Branch Ausable River near Lake } \\
\text { Placid }\end{array}$ & 116 & $\begin{array}{l}1916-17 \\
1919-68\end{array}$ & $09-22-38$ & 12.20 & 10,800 & 93.1 & 27 & 0100 & 8.36 & 4,260 & 36.7 \\
\hline 04275000 & $\begin{array}{l}\text { East Branch Ausable River at Au Sable } \\
\text { Forks }\end{array}$ & 198 & $1924-$ & $09-22-38$ & 12.91 & 20,100 & 102 & 27 & a 0300 & 11.13 & 15,200 & 76.8 \\
\hline 04275500 & Ausable River near Au Sable Forks & 448 & $1910-68$ & $09-22-38$ & 11.65 & 24,200 & 54.0 & 27 & - & 10.13 & 18,000 & 40.2 \\
\hline 04276200 & Bouquet River at New Russia & 37.6 & $\begin{array}{l}1949,51, \\
53,56-63, \\
65-67, \\
71-73,77\end{array}$ & $12-21-57$ & 13.50 & 4,480 & 119 & 26 & - & 16.76 & 6,400 & 170 \\
\hline 04276215 & The Branch near Elizabethtown & 19.1 & - & - & - & - & - & 26 & - & - & 6,600 & 345 \\
\hline 04276500 & Bouquet River at Willsboro & 275 & $1923-68$ & $10-01-24$ & 10.85 & 11,800 & 42.9 & 27 & - & 9.6 & 9,300 & 33.8 \\
\hline 04278300 & Northwest Bay Brook near Bolton Landing & 23.4 & $1965-$ & $12-21-73$ & 6.15 & 1,650 & 70.5 & 26 & 2215 & 4.42 & 769 & 32.9 \\
\hline
\end{tabular}

a about 


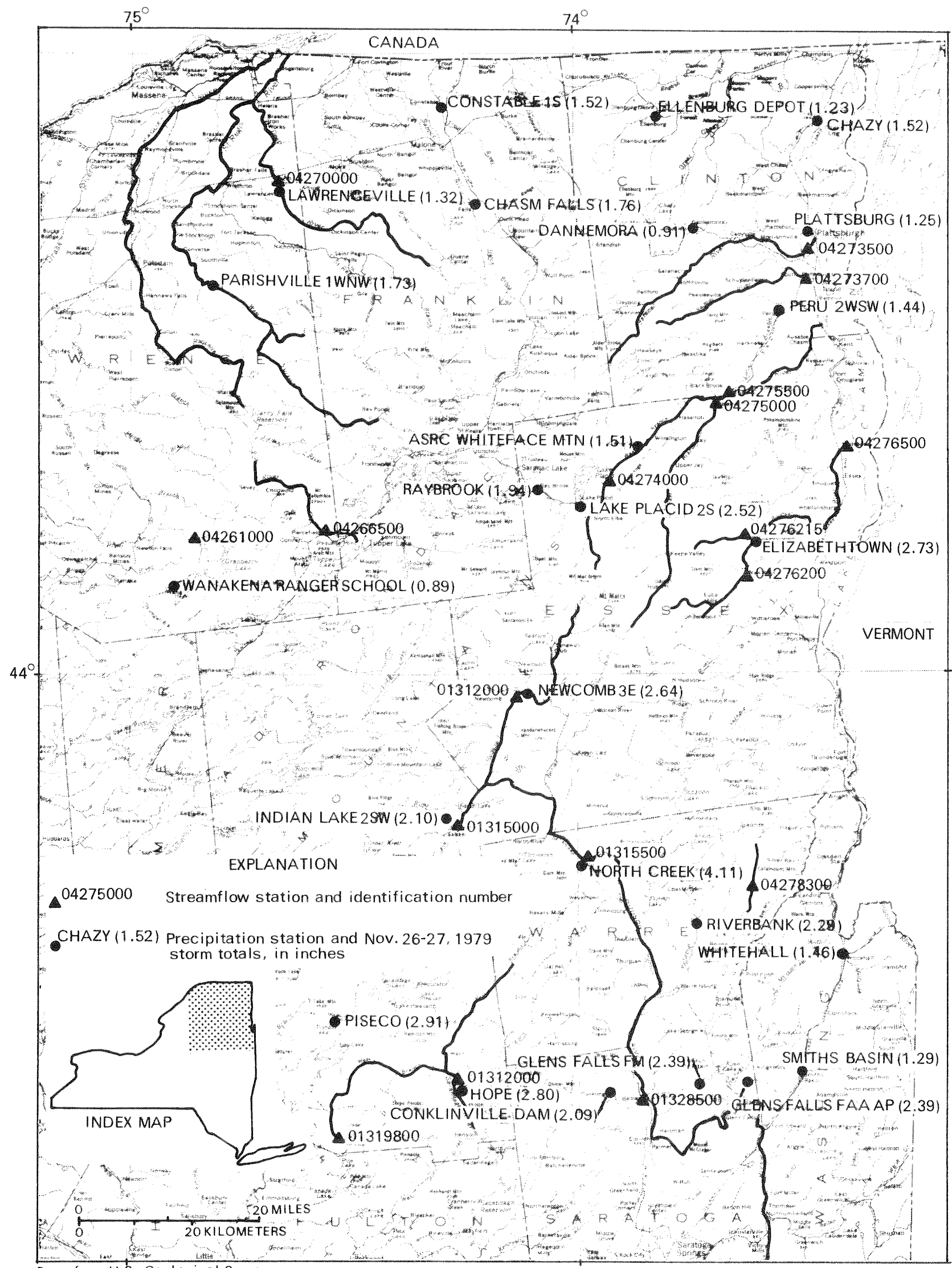

Base from U.S. Geological Survey

State base map, 1974

Figure 3.--Location of gaging stations and precipitation gages in northeastern New York. 
Recurrence intervals were assigned to the discharges on the gaged streams that had the most severe flooding (recurrence interval equal to or greater than 2 years). These probabilities, listed in table 2, are based on the frequency curves computed for these stations by Zembrzuski and Dunn (1979).

A flood-frequency curve was developed for The Branch at the site of the indirect measurement by procedures outlined by Zembrzuski and Dunn (1979) for ungaged rural streams (fig. 4). This curve indicates that the recurrence interval of the November 26 flood was greater than 100 years.

Table 2.--Recurrence interval of discharges of selected streams during flood of November 26-27, 1979, Elizabethtown, N.Y.

[Station locations are shown in fig. 3]

\begin{tabular}{|c|c|c|c|}
\hline $\begin{array}{l}\text { Station } \\
\text { Number }\end{array}$ & $\begin{array}{l}\text { Stream name } \\
\text { and Location }\end{array}$ & $\begin{array}{l}\text { Discharge } \\
(\mathrm{ft} 3 / \mathrm{s})\end{array}$ & $\begin{array}{l}\text { Recurrence } \\
\text { interval }\end{array}$ \\
\hline 01315500 & Hudson River at North Creek & 13,300 & 2 \\
\hline 01319800 & $\begin{array}{l}\text { West Branch Sacandaga River at } \\
\text { Arietta }\end{array}$ & 1,050 & 2 \\
\hline 01321000 & Sacandaga River near Hope & 14,900 & 3 \\
\hline 04274000 & $\begin{array}{l}\text { West Branch Ausable River near } \\
\text { Lake Placid }\end{array}$ & 4,260 & 5 \\
\hline 04275000 & $\begin{array}{l}\text { East Branch Ausable River at } \\
\text { Au Sable Forks }\end{array}$ & 15,200 & 50 \\
\hline 04275500 & Ausable River near Au Sable Forks & 18,000 & 15 \\
\hline 04276200 & Bouquet River at New Russia & 6,400 & $>100$ \\
\hline 04276215 & The Branch near Elizabethtown & 6,600 & $>100$ \\
\hline 04276500 & Bouquet River at Willsboro & 9,300 & 25 \\
\hline
\end{tabular}

\section{PRECIPITATION}

Location of precipitation gages in the region and their measured totals from the November 25-26, 1979 storm are given in figure 2 . It is difficult to estimate the intensity of that storm because, in areas of most severe flooding, no recording rainfall gages have been installed. The recording precipitation gage closest to Elizabethtown is at the Atmospheric Sciences Research Center on Whiteface Mountain, about 20 miles north of Elizabethtown. The heaviest rain fell during a 3-hour period, beginning at about 1700 hours on November 26, during which time 0.80 inch was recorded. 


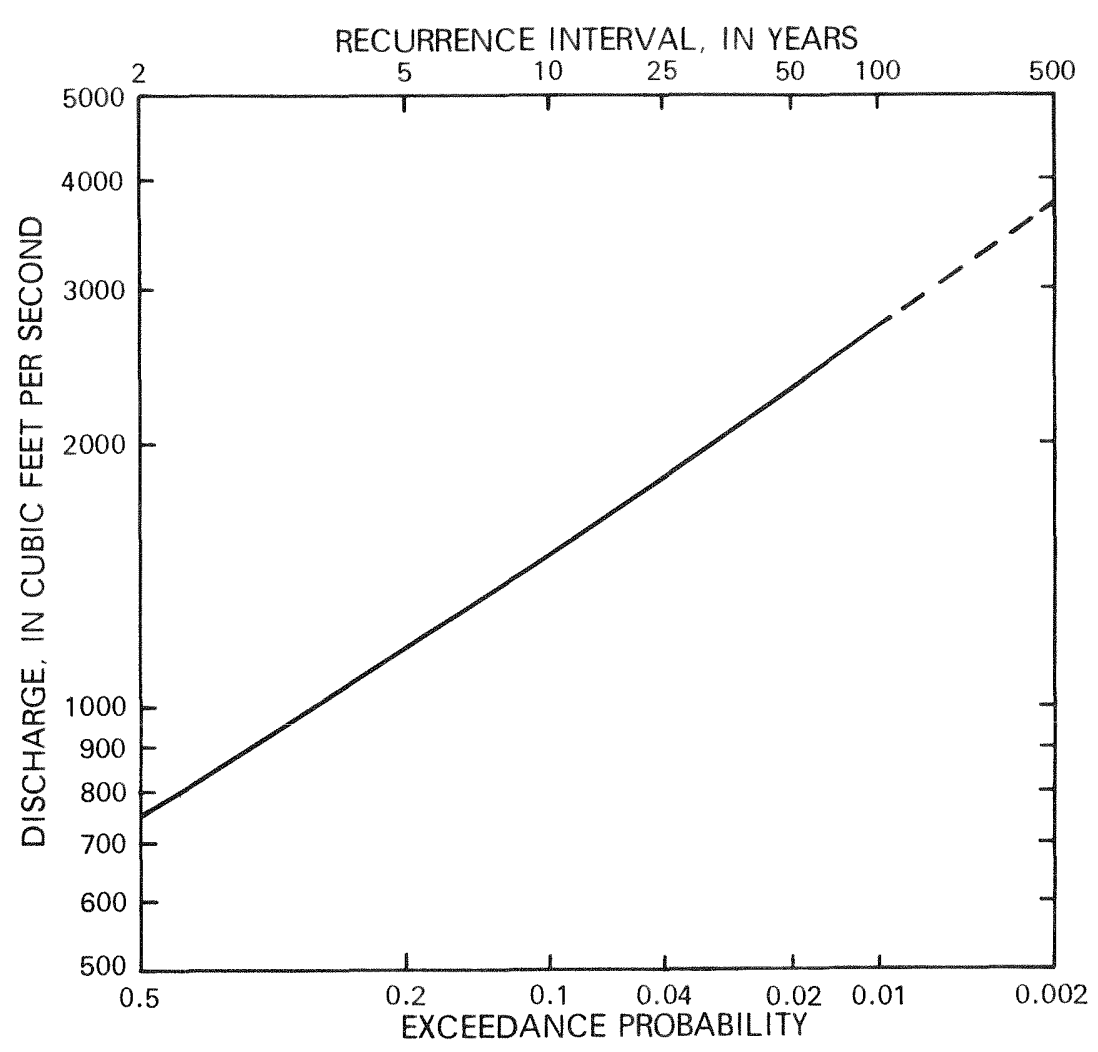

Figure 4.--Flood-frequency curve for station 04276215

The Branch near Elizabethtown, N.Y.

The National Weather Service observer in Elizabethtown measured 1.45 inches between 1300 hours on November 26 and 0800 hours the next day. At North Creek, where the greatest storm total was recorded, the observer noted that 1.52 inches fel1 on November 26 between 1300 and 1730 hours, and that an additional 0.83 inches fell between 1730 and 1900 hours.

NWS made an inspection trip after the storm in an attempt to further document rainfall totals but achieved only slight success because the mountains surrounding the flooded areas are sparsely populated. A container found 1 mile south of Keene (fig. 1) had collected 5 inches of rain during the storm. Data from the precipitation-gage network do not corroborate the severity of the floods on some of the streams. Rainfal1-frequency relationships for storms of 3-hour and 6-hour duration (U.S. Weather Bureau, 1961) are given in table 3 . 
Much higher intensities and storm totals are likely in the headwaters of the Bouquet River basin and its tributaries than were indicated by the precipitation gages.

Table 3.--Rainfall-frequency relationships for storms of

3- and 6-hour duration, Essex County, N.Y.

[Data from U.S. Weather Bureau, 1961]

\begin{tabular}{ccc}
\hline $\begin{array}{c}\text { Recurrence } \\
\text { interval } \\
\text { (years) }\end{array}$ & $\begin{array}{c}\text { Depth for 3-hour } \\
\text { duration } \\
\text { (inches) }\end{array}$ & $\begin{array}{c}\text { Depth for 6-hour } \\
\text { duration } \\
\text { (inches) }\end{array}$ \\
\hline 1 & 1.2 & 1.5 \\
2 & 1.5 & 1.8 \\
5 & 1.9 & 2.3 \\
10 & 2.2 & 2.6 \\
25 & 2.5 & 3.0 \\
50 & 2.9 & 3.5 \\
100 & 3.2 & 3.8 \\
\hline
\end{tabular}

\section{SUMMARY}

A storm on November 25 and 26, 1979, in northeastern New York, resulted in flash flooding of several streams in Essex County. Floodwaters from The Branch, a tributary to the Bouquet River, caused a washout of State Highway $9 \mathrm{~N}, 2$ miles west of Elizabethtown, that claimed five lives. Peak discharge of The Branch at a measurement site 0.7 mile downstream from the washout was $6,600 \mathrm{ft} 3 / \mathrm{s}$; peak discharge at the crest-stage gage on the Bouquet River at New Russia (station 04276200), was $6,400 \mathrm{ft} 3 / \mathrm{s}$, the highest in its 31-year period of record. The recurrence interval of both discharges is greater than 100 years. The recurrence interval of the flood on East Branch Ausable River at Au Sable Forks (station 04275000) is 50 years.

Rainfal1 data from the precipitation-gage network do not corroborate the severity of the floods on some of the streams. Although only 2.73 inches was measured at the gage in Elizabethtown, an unofficial report from the mountains west of Elizabethtown indicates that rainfall totals could have exceeded 5 inches in some areas. 


\section{REFERENCES CITED}

Brady, Wi11, 1979, Flash flood hits area with death and destruction: Valley News, Elizabethtown, N.Y.; Denton Publications, November 29, 1979 issue, p $14-15$.

Dalrymple, Tate, and Benson, M. A., 1967, Measurement of peak discharge by the slope-area method: U.S. Geological Survey Techniques of Water-Resources Investigations, Book 3, Chap. A2, 12 p.

Nationa1 Oceanic and Atmospheric Administration, 1980, C1imatologica1 Data for New York: November 1979, 91, no. 11, 22 p.

U.S. Weather Bureau, 1961, Rainfal1 frequency atlas of the United States:

U.S. Weather Bureau (National Weather Service) Technical Paper 40, 115 p.

Zembrzuski, T. J., and Dunn, Bernard, 1979, Techniques for estimating magnitude and frequency of floods on rural unregulated streams in New York State excluding Long Island: U.S. Geological Survey Water-Resources Investigations 79-83, 66 p. 